\title{
Pengaruh Penggunaan Tepung Daging Bekicot (Achatina fulica) pada Pakan Buatan terhadap Pertumbuhan, Rasio, Konversi Pakan dan Tingkat Kelulushidupan Benih Ikan Patin (Pangasius pangasius)
}

\author{
Effect of Use of Snail Meat (Achatina fulica) for Artificial Diet on \\ Growth, Food Convertion and Survival Rate Catfish (Pangasius pangasius)
}

\author{
Boedi Setya Rahardja, Devieta Sari dan Moch. Amin Alamsjah
}

Fakultas Perikanan dan Kelautan Universitas Airlangga Kampus C Mulyorejo - Surabaya, 60115 Telp. 031 - 5911451

\begin{abstract}
Currently catfish is experiencing a fairly rapid growth, this is because the catfish is one of the important commodities in the fishery. Efforts to increase catfish production is to improve the quality of feed. The aim of this study is to observe effect of snail meat meal for growth rate, food conversion ratio and survival rate of catfish seeds.

This research method is experimental with a Completely Randomized Design (CRD) with five treatments and four replications. The treatments were used: (A) $0 \%$ snail meat meal, (B) $10 \%$ snail meat meal and 30\% fish meal, (C) $20 \%$ snail meat meal and 20\% fish meal, (D) 30\% snail meat meal and $10 \%$ fish meal and (E) $40 \%$ snail meat meal. The main parameters measured were growth, feed conversion ratio and survival rate. Supporting parameters measured were water quality. Analysis of the data used is Analysis of variance (ANOVA) and to know the difference among treatment using Duncan's Multiple Range Test. The results of this study showed that use of snail meat meal in feed formulation stastistically difference $(\mathrm{p}<0.05)$ for growth and survival rate of catfish seeds but not statistically difference $(\mathrm{p}>0.05)$ for feed conversion ratio. Water quality in maintenance media seed catfish is the temperature range between $26-31^{\circ} \mathrm{C}, \mathrm{pH} 7-8$ and dissolved oxygen was $7.2-8.0 \mathrm{mg} / \mathrm{L}$.
\end{abstract}

Keywords : Pangasius pangasius, food, snail meat meal, growth, food convertion ratio, survival rate

\section{Latar Belakang}

Ikan patin merupakan ikan ekonomis penting, baik pada tingkat benih sebagai ikan hias maupun pada tingkat dewasa sebagai ikan konsumsi. Sebagai ikan hias, ikan patin memiliki bentuk tubuh yang khas, perenang cepat dan mudah dalam pemeliharaan, sedangkan sebagai ikan konsumsi, ikan patin sangat digemari masyarakat karena memiliki daging yang tebal dan gurih (Hardjamulia dkk., 1986 dalam Haetami dkk., 2007).

Ikan patin merupakan jenis ikan konsumsi air tawar yang memiliki kandungan protein cukup tinggi (Amri dan Susanto, 2002). Rasa daging ikan patin sangat enak, gurih dan lezat sehingga digemari oleh masyarakat. Ikan patin mengandung protein sebesar 68,6\%, lemak 5,8\%, abu 3,5\% dan air 59,3\% (Kordi, 2010). Ikan patin juga dinilai lebih aman untuk kesehatan karena mengandung kadar kolesterol yang rendah dibandingkan dengan daging hewan ternak (Amri dan Susanto, 2002).

Benih ikan patin membutuhkan pakan buatan yang mengandung protein lebih dari 30\% (BSNI, 2009). Pakan buatan yang mengandung protein $35 \%$, memberikan pertumbuhan yang terbaik pada benih ikan patin (Kordi, 2010). Pakan tersebut dapat berupa pakan alami maupun pakan buatan (Sahwan, 2002). Pakan buatan adalah pakan yang diformulasikan sendiri dari beberapa macam bahan, kemudian diolah menjadi bentuk khusus sebagaimana yang dikehendaki (Mudjiman, 2001). Pakan buatan disusun menurut kebutuhan ikan, maka dari itu formulasi dan bentuk pakan merupakan modifikasi pakan alami yang disesuaikan dengan kebutuhan masing-masing jenis dan tingkat pertumbuhan serta perkembangan ikan. Kandungan nutrisi yang diperlukan oleh ikan pada umumnya terdiri dari lima kelompok, yaitu : protein, karbohidrat, lemak, mineral dan vitamin (Agustono dkk., 2007).

Bahan baku utama dalam ransum pakan buatan yang umumnya dipakai adalah tepung ikan dengan kandungan nutrisi menurut Gusrina (2008) adalah protein $62,65 \%$, lemak $6,5 \%$ dan karbohidrat $8,5 \%$, akan tetapi bahan baku utama pada pakan buatan dapat juga menggunakan bahan baku yang lain seperti tepung daging bekicot. Murtidjo (1987) menyatakan bahwa tepung daging bekicot sebagai bahan baku pakan, sangat dominan dimanfaatkan untuk pengganti bahan baku tepung ikan dalam ransum pakan karena diketahui memiliki nutrisi yang sebanding dengan tepung ikan. Sahwan (2002) menyatakan bahwa kandungan nutrisi pada tepung daging bekicot adalah proten berkisar antara 54,2964,14\%, lemak 3,92-4,18\%, karbohidrat 30,45\%. Murtidjo (1987) menyatakan bahwa penggunaan tepung daging bekicot optimum dalam penyusunan pakan buatan hingga $25 \%$. 
Dengan melihat kandungan nutrisi pada tepung bekicot dan tepung ikan, apakah terdapat perbedaan pada pertumbuhan, rasio konversi pakan dan tingkat kelulushidupan benih ikan patin apabila keduanya diberikan pada ransum pakan dengan komposisi yang berbeda. Penelitian ini lebih menitikberatkan pada penggunaan tepung daging bekicot sebagai bahan baku pakan utama yang terdapat pada ransum pakan buatan. Tepung ikan yang biasanya digunakan sebagai bahan utama dalam pembuatan pakan buatan akan diganti dengan tepung daging bekicot.

\section{Tujuan}

Mengetahui pengaruh penggunaan tepung daging bekicot pada pakan buatan terhadap pertumbuhan benih ikan patin.

Mengetahui pengaruh penggunaan tepung daging bekicot pada pakan buatan terhadap rasio konversi pakan benih ikan patin.

Mengetahui pengaruh penggunaan tepung daging bekicot pada pakan buatan terhadap tingkat kelulushidupan benih ikan patin.

\section{Manfaat}

Penelitian ini diharapkan dapat memberikan informasi mengenai penggunaan tepung daging bekicot pada pakan buatan yang memberikan hasil maksimal terhadap pertumbuhan, rasio konversi pakan dan tingkat kelulushidupan benih ikan patin.

\section{Metodologi Penelitian}

Penelitian ini dilakukan di Fakultas Perikanan dan Kelautan, Universitas Airlangga. Analisis proksimat bahan baku pakan dilakukan di Unit Layanan Pemeriksaan Laboratoris, Konsultasi dan Pelatihan Fakultas Kedokteran Hewan, Universitas Airlangga, Surabaya. Waktu pelaksanaan penelitian pada tanggal 30 Januari sampai dengan 19 Februari 2011.

Penelitian ini menggunakan metode eksperimental yang bertujuan untuk mengetahui kemungkinan hubungan sebab akibat dengan cara memberikan satu atau lebih kondisi perlakuan dan membandingkan hasilnya dengan satu atau lebih kelompok kontrol yang tidak diberikan perlakuan (Narbuko dan Achmadi, 2004).

Rancangan penelitian yang digunakan adalah Rancangan Acak Lengkap (RAL). Perlakuan yang digunakan dalam penelitian ini adalah persentase penggunaan tepung daging bekicot pada ransum pakan yaitu sebanyak lima perlakuan dan empat ulangan. Perlakuan A, yaitu pemakaian tepung daging bekicot $0 \%$. Perlakuan $\mathrm{B}$, yaitu pemakaian tepung daging bekicot $10 \%$. Perlakuan $\mathrm{C}$, yaitu pemakaian tepung daging bekicot $20 \%$. Perlakuan D, yaitu pemakaian tepung daging bekicot $30 \%$ dan perlakuan E, yaitu pemakaian tepung daging bekicot $40 \%$.

Ikan coba yang digunakan dalam penelitian adalah benih ikan patin dengan umur 14 hari, ukuran panjang tubuh berkisar antara 3-4 cm dan berat tubuh berkisar antara 0,4-0,5 gram. Alat yang digunakan dalam penelitian ikan patin adalah akuarium yang berukuran $40 \times 25 \times 25 \mathrm{~cm} 3$, selang penyipon, seser, timbangan digital, penggaris besi, $\mathrm{pH}$ paper, termometer, DO meter. Bahan baku pakan yang akan digunakan dalam penelitian ini adalah tepung daging bekicot, tepung ikan, tepung kedelai, tepung jagung, dedak padi, tepung terigu, tepung tapioka, minyak ikan, mineral dan vitamin mix.

Bahan baku pakan yang akan digunakan dalam ransum pakan dianalisis priksimat terlebih dahulu untuk mengetahui kandungan nutrisi yang terdapat dalam bahan tersebut. Bahan baku pakan yang sudah dianalisis proksimat, kemudian ditentukan komposisi pakan antar perlakuan dengan kandungan protein sebesar 35\%. Hal ini sesuai dengan pernyataan Kordi (2010) bahwa pakan buatan dengan kandungan protein sebesar 35\% memberikan pertumbuhan yang terbaik pada benih ikan patin. Formulasi pakan dihitung menggunakan metode uji coba. Bahan baku yang masih kasar diayak terlebih dahulu, sehingga menghasilkan bahan baku yang lebih lembut. Semua bahan baku yang sudah siap, ditimbang sesuai dengan formulasi yang sudah ditentukan kandungan protein dalam ransum pakan. Selanjutnya adalah pencampuran bahan baku, dimulai dari gram atau persentasenya paling sedikit hingga yang paling banyak ke dalam wadah yang sudah disiapkan. Semua bahan baku diaduk sampai merata, kemudian dimasukkan ke dalam panci pengukus selama 30 menit. Bahan baku yang sudah selesai dikukus, langsung dilakukan pencetakan menggunakan alat pencetak khusus pellet. Pakan yang sudah selesai dicetak, diangin-anginkan selama sepuluh menit, kemudian dilakukan pemotongan. Pakan buatan yang setengah jadi, dikeringkan selama 24 jam dengan menggunakan oven. Pakan buatan antar perlakuan yang sudah jadi dilakukan analisis proksimat untuk mengetahui kandungan nutrisinya, kemudian pakan diberikan pada benih ikan patin sesuai dengan perlakuan. 
Persiapan penelitian meliputi sterilisasi alat dan media pemeliharaan. Media pemeliharaan yang digunakan dalam penelitian ini adalah air tawar. Air tersebut ditempatkan ke dalam 20 akuarium. Tiap akuarium diisi air dengan volume 20 liter. Sebelum dilakukan penebaran benih ikan patin, terlebih dahulu air disterilisasi dengan filterisasi selama tiga hari. Semua peralatan yang akan digunakan dalam penelitian juga disterilisasi terlebih dahulu dengan menggunakan klorin 400 ppm kemudian dibilas dengan menggunakan air bersih kemudian dibilas dengan air bersih dan dikeringkan (BBL, 2003). Tujuan sterilisasi alat dan media pemeliharaan adalah agar organism penyebab penyakit dapat dimusnahkan dan kotoran serta senyawa beracun dapat dinetralkan (Afrianto dan Liviawaty, 1992).

Benih ikan patin yang digunakan dalam penelitian ini berumur 14 hari dengan panjang tubuh berkisar antara 3-4 $\mathrm{cm}$ dan berat tubuh berkisar antara 0,4-0,5 g. Benih ikan patin didapatkan dari Unit Pengelola Budidaya Air Tawar (UPBAT) Mojokerto. Benih ikan patin ditempatkan dalam akuarium. Setiap perlakuan menggunakan 4 akuarium dan tiap akuarium diisi benih ikan patin sebanyak lima ekor. Sebelum ditebar benih ikan patin diaklimatisasi selama 30 menit. Tujuan aklimatisasi menurut BBL (2002) yaitu mengurangi stress pada benih ikan akibat perubahan suhu sehingga dapat beradaptasi dengan kondisi lingkungan perairan yang baru. Selain itu benih ikan patin juga diadaptasikan dengan pakan buatan selama satu minggu.

Pemberian pakan dilakukan sebanyak dua kali sehari, yaitu pada pukul 08.00 WIB dan 16.00 WIB. Pakan diberikan setiap hari sebanyak 4\% dari biomassa (Umphan, 2009). Pengamatan parameter utama, yaitu laju pertumbuhan, rasio konversi pakan dan tingkat kelulushidupan benih ikan patin dilakukan setiap tujuh hari sekali, sedangkan untuk pengamatan parameter penunjang, yaitu suhu, $\mathrm{pH}$ dan oksigen terlarut dilakukan setiap hari pada pukul 06.00, 14.00 dan 20.00 WIB.

Parameter utama pada penelitian ini adalah pertumbuhan ikan, rasio konversi pakan dan tingkat kelulushidupan benih ikan patin. Pertumbuhan meliputi pertambahan berat dan pertambahan panjang. Penghitungan parameter uji utama dilakukan setiap satu minggu sekali dari awal sampai akhir penelitian. Penghitungan dilakukan pada akhir penelitian. Penelitian ini dilakukan selama 21 hari pemeliharaan benih ikan patin dalam akuarium.

Parameter penunjang pada penelitian adalah pengukuran kualitas air meliputi suhu, $\mathrm{pH}$ yang diukur setiap hari pada pukul 06.00, 14.00 dan 17.00 WIB. Oksigen terlarut yang diukur pada awal, tengah dan akhir penelitian yaitu pada pukul $06.00,14.00$ dan 17.00 WIB.

Analisis statistik menggunakan Analysis of Varian (ANOVA) untuk mengetahui pengaruh perlakuan. Apabila dari analisis ragam diketahui bahwa perlakuan menunjukkan pengaruh yang berbeda nyata atau berbeda sangat nyata, maka untuk membandingkan pengaruh perlakuan dilanjutkan $\mathrm{Uji}$ Jarak Berganda Duncan (Kusriningrum, 2008).

\section{Hasil dan Pembahasan}

Hasil penlitian dari perlakuan pengaruh penggunaan tepung daging bekicot pada ransum pakan dengan persentase yang berbeda menunjukkan perbedaan yang nyata $(\mathrm{p}<0,05)$ terhadap laju pertumbuhan dan tingkat kelulushidupan. Akan tetapi hasil yang tidak menunjukkan perbedaan nyata $(p>0,05)$ tedapat pada rasio konversi pakan benih ikan patin.

Hasil analisis statistik menunjukkan bahwa laju pertumbuhan berbeda nyata antar perlakuan $(p<0,05)$. Laju pertumbuhan tertinggi terdapat pada perlakuan B $(2,346 \%)$ dengan penggunaan tepung daging bekicot sebesar $10 \%$ tetapi tidak berbeda nyata dengan perlakuan A $(2,319 \%)$ dengan penggunaan $40 \%$ tepung ikan. Laju pertumbuhan yang paling rendah ditunjukkan pada perlakuan D (1,641\%) dengan penggunaan tepung daging bekicot sebesar 30\% yang tidak berbeda nyata dengan perlakuan C $(1,869 \%)$ dengan penggunaan tepung daging bekicot $20 \%$ dan perlakuan E $(1,701 \%)$ dengan penggunaan tepung daging bekicot $40 \%$. Hal tersebut menunjukkan bahwa penggunaan tepung daging bekicot dalam ransum pakan tidak dapat menunjukkan laju pertumbuhan yang lebih baik dibandingkan dengan penggunaan tepung ikan.

Ikan membutuhkan protein untuk melakukan pertumbuhan (Lovell, 1988). Kualitas protein bahan baku pakan dapat dilihat dari kandungan asam amino esensial di dalamnya. Asam amino esensial sangat mutlak dibutuhkan oleh hewan dan harus tersedia dalam makanannya, karena asam amino esensial tidak dapat diproduksi di dalam tubuh hewan itu sendiri (Mujiman, 1994). Setidaknya ada 10 jenis asam amino esensial yang harus tersedia dalam pakan, yaitu leusin, metionin, isoleusin, triptofan, valin, arginin, histidin, fenilalamin, treonin dan lisin (Akbar, 2000).

Tepung ikan memiliki sepuluh macam asam amino esensial, yaitu arginin, histidin, isoleusin, 
leusin, lysin, methionin, phenylalanin, threonin, tryptophan dan valin (Bureau dan Cho, 1999). Sedangkan tepung daging bekicot hanya memiliki sembilan macam asam amino esensial, yaitu arginin, histidin, isoleusin, leusin, lysin, methionin, phenylalanin, threonin dan valin (Sogbesan dan Ugwumba, 2008). Berdasarkan kandungan asam amino esensialnya, tepung ikan memiliki kualitas yang lebih baik daripada tepung daging bekicot, sehingga penggunaan tepung daging bekicot dalam ransum pakan tidak menunjukkan laju pertumbuhan yang lebih baik dibandingkan dengan penggunaan tepung ikan dalam ransum pakan.

Kemampuan ikan untuk memanfaatkan karbohidrat tergantung pada kemampuannya untuk menghasilkan enzim amilase, dan kemampuan ini tergantung pula pada jenis ikannya. Ikan karnivora sangat sedikit membutuhkan karbohidrat (Mudjiman, 1994). Hal ini disebabkan karena ikan tidak memiliki kelenjar air liur, sehingga proses pencernaan karbohidrat pada ikan dimulai dibagian lambung. Pencernaan karbohidrat secara intensif terjadi disegmen usus yaitu dengan adanya enzim amilase pankreatik. Pada segmen usus, amilum (zat tepung) dan glikogen akan dihidrolisis oleh enzim amilase menjadi maltosa dan dekstrin, Kemudian maltosa dan dekstrin ini akan dihidrolisa oleh enzim laktase atau sukrose menghasilkan galaktosa, glukosa dan fruktosa. Pada dinding usus, galaktosa dan fruktosa akan diubah menjadi glukosa. Dalam bentuk glukosa itulah karbohidrat dapat diserap oleh dinding sel (enterosit) lalu masuk kedalam pembuluh darah, kemudian digunakan untuk metabolisme dalam tubuh (Fujaya, 2004).

Penggunaan karbohidrat yang terlalu tinggi dapat menghambat laju pertumbuhan, demikian pula sebaliknya (Wilson, 1994). Ikan karnivora umumnya mempunyai kemampuan yang lebih rendah dalam memanfaatkan karbohidrat pakan dibandingkan dengan ikan karnivora atau herbivora. Penyebab rendahnya kemampuan ikan dalam memanfaatkan karbohidrat pakan antara lain disebabkan oleh nilai kecernaan sumber karbohidrat, aktivitas enzim karboksilase ikan, kemampuan penyerapan glukosa serta kemampuan sel memanfaatkan glukosa dalam darah. Ikan yang kekurang karbohidrat pakan juga dapat mempengaruhi pertumbuhan ikan. Kebutuhan nutrisi pakan ikan harus sesuai dengan kebutuhan ikan. Apabila dalam pakan ikan tersebut terdapat salah satu nutrisi yang kurang maka kebutuhannya akan digantikan dengan nutrisi yang lain. Misalnya kebutuhan karbohidrat pada pakan ikan kurang, maka peran karbohidrat akan digantikan dengan protein. Protein dalam pakan ikan memiliki fungsi utama yaitu untuk pertumbuhan ikan, apabila fungsi tersebut dipecah untuk sumber energi, maka peran dari protein tersebut tidak maksimal, sehingga dapat menghambat pertumbuhan ikan (Gusrina, 2008). Hal ini dapat dilihat pada hasil analisis pakan buatan dimana pada perlakuan B dengan kandungan karbohidrat 32,38\% menunjukkan laju pertumbuhan tertinggi di antara perlakuan yang lain. Berbeda dengan perlakuan D yang menunjukkan laju pertumbuhan paling rendah dengan kandungan karbohidrat pada pakan tertinggi di antara perlakuan yang lain yaitu sebesar 40,13\%.

Lemak dalam pakan mempunyai peranan yang penting sebagai sumber tenaga, bahkan jika dibandingkan dengan protein dan karbohidrat, lemak dapat menghasilkan tenaga yang lebih besar (Mudjiman, 1994). Lemak merupakan nutrisi esensial yang mempengaruhi pertumbuhan ikan (Lovell, 1988). Kekurangan lemak dapat mengakibatkan lambatnya pertumbuhan ikan (Akbar, 2000). Hasil analisis proksimat pakan pada perlakuan B dengan kandungan lemak sebesar 15,52\% menunjukkan laju pertumbuhan tertinggi di antara perlakuan lain. Laju pertumbuhan terendah terdapat pada perlakuan D dengan kandungan lemak pada pakan sebesar 9,41\%.

Kisaran energi yang dapat dicerna antara 3.334,87-3.371,77 kkal/kg pakan yang terdapat pada perlakuan A dan perlakuan B menunjukkan laju pertumbuhan yang lebih tinggi dibandingkan dengan perlakuan $\mathrm{C}$, perlakuan $\mathrm{D}$ dan perlakuan $\mathrm{E}$ dengan kisaran energi yang dapat dicerna antara 3.071,66$3.144,77 \mathrm{kkal} / \mathrm{kg}$ pakan. Hal tersebut menunjukkan bahwa semakin tinggi energi yang dapat dicerna dapat meningkatkan laju pertumbuhan ikan patin.

Hasil perhitungan statistik menunjukkan bahwa nilai rasio konversi pakan tidak berbeda nyata antar perlakuan $(\mathrm{p}>0,05)$. Hal tersebut menunjukkan bahwa penggunaan tepung daging bekicot dalam ransum pakan tidak dapat memberikan rasio konversi pakan yang lebih baik dibandingkan dengan penggunaan tepung ikan saja dalam ransum pakan. Kualitas pakan yang menggunakan tepung daging bekicot tidak lebih baik daripada yang hanya menggunakan tepung ikan.

Hasil uji statistik menunjukkan bahwa terdapat perbedaan nyata antar perlakuan $(\mathrm{p}<0,05)$. Tingkat kelulushidupan tertinggi terdapat pada perlakuan B tetapi tidak berbeda nyata $(p<0,05)$ dengan perlakuan A, sedangkan tingkat 
kelulushidupan terendah terdapat pada perlakuan $\mathrm{C}$ yang tidak berbeda nyata $(p<0,05)$ dengan perlakuan D dan E. Berdasarkan analisis statistik tersebut diketahui bahwa pemberian tepung daging bekicot sebanyak $10 \%$ pada perlakuan B tidak dapat menunjukkan kelangsungan hidup yang lebih baik daripada perlakuan A dengan menggunakan tepung ikan sebanyak 40\%, hal ini menunjukkan bahwa kualitas pakan dengan menggunakan tepung daging bekicot dalam ransum pakan ikan patin tidak lebih baik jika dibandingkan dengan kualitas pakan yang hanya menggunakan tepung ikan saja.

Parameter kualitas air yang terukur selama masa penelitian, antara lain adalah suhu berkisar antara 26-31o C, pH berkisar antara 7-8 dan oksigen terlarut berkisar antara 7,2-8 $\mathrm{mg} / \mathrm{L}$. Parameter kualitas air tersebut sudah sesuai dengan BSNI (2000) yang menyatakan bahwa ikan patin dapat tumbuh optimal pada suhu 27-32o C, pH antara 6,58,5 dan oksigen terlarut lebih dari $5 \mathrm{mg} / \mathrm{L}$.

\section{Kesimpulan}

Penggunaan tepung daging bekicot pada pakan buatan dengan persentase yang berbeda memberikan pengaruh yang nyata terhadap pertumbuhan benih ikan patin. Laju pertumbuhan tetinggi diperoleh pada perlakuan B $(2,346 \%)$ y a $\mathrm{ng}$ tidak berbeda nyata dengan perlakuan A $(2,319 \%)$ dan laju pertumbuhan terendah diperoleh pada perlakuan D $(1,641 \%)$ yang tidak berbeda nyata dengan perlakuan $\mathrm{C}(1,865 \%)$ dan $\mathrm{E}(1,701 \%)$.

Penggunaan tepung daging bekicot pada pakan buatan dengan persentase yang berbeda tidak memberikan pengaruh yang nyata terhadap rasio konversi pakan benih ikan patin.

Penggunaan tepung daging bekicot pada pakan buatan dengan persentase yang berbeda memberikan pengaruh yang nyata terhadap tingkat kelulushidupan benih ikan patin. Tingkat kelulushidupan benih ikan patin tertinggi diperoleh pada perlakuan B (100\%) yang tidak berbeda nyata dengan perlakuan A $(95 \%)$ dan tingkat kelulushidupan terendah diperoleh pada perlakuan $\mathrm{C}$ $(50 \%)$ yang tidak berbeda nyata dengan perlakuan $\mathrm{D}$ $(50 \%)$ dan E (65\%).

Berdasarkan hasil penelitian yang telah dilakukan bahwa untuk menghasilkan laju pertumbuhan yang cepat dan tingkat kelulushidupan yang tinggi disarankan penggunaan tepung daging bekicot pada ransum pakan buatan adalah sebesar $10 \%$ atau tanpa penggunaan tepung daging bekicot pada ransum pakan buatan.

\section{Daftar Pustaka}

Afrianto, E dan E. Liviawaty. 1992. Pengendalian Hama dan Penyakit Ikan. Kanisius. Jakarta. hal. 33 .

Agustono., W. P. Lokapirnasari, H. Setyono dan T. Nurhajati. 2007. Pengantar Teknologi Pakan Ikan. Universitas Airlangga. hal. 2937.

Akbar, S. 2000. Meramu Pakan Ikan Kerapu (Bebek, Lumpur, Macan, Malabar). Penebar Swadaya. Jakarta. hal. 7.

Amri, K dan Susanto, H. 2002. Budidaya Ikan Patin. Penebar Swadaya. Jakarta. 90 hal.

Badan Standardisasi Nasional Indonesia (BSNI). 2000. Produksi Benih Ikan Patin Siam (Pangasius hyphopthalmus) Kelas Benih Sebar. SNI : 01-6483.4. Jakarta. www.perikanan-budidaya.dkp.go.id. 23 Oktober 2010. 13 hal.

Badan Standardisasi Nasional Indonesia (BSNI). 2009. Ikan Patin Djambal (Pangasius djambal). Bagian 3 : Kelas Benih Sebar. SNI : 7471.3. Jakarta. www.perikananbudidaya.dkp.go.id. 23 Oktober 2010. 12 hal.

Bureau, D. P and Cho, C. Y. 1999. An Introduction to Nutrition and Feeding of Fish. Fish Nutrition Research Laboratory Departement of Animal and Poultry Science. University of Guelph, Ontario. Canada. www.scritube.com. 04 Maret 2011. 36 hal.

Balai Budidaya Laut (BBL). Direktorat Jenderal Perikanan Budidaya Departemen Kelautan Dan Perikanan. 2002. Pengelolaan Kesehatan Ikan Budidaya Laut. ISBN : 979-95483-8-1. No : 10. Lampung. hal. 17.

Balai Budidaya Laut (BBL). Direktorat Jenderal Perikanan Budidaya Departemen Kelautan Dan Perikanan. 2003. Penanganan Penyakit Ikan Budidaya Laut. ISBN : 979-98017-10. No : 12. Lampung. hal. 24.

Fujaya, Y. 2004. Fisiologi Ikan : Dasar Pengembangan Teknik Perikanan. Rineka Cipta. Jakarta. hal. 131.

Gusrina, 2008b. Budidaya Ikan. Edisi kedua. Departemen Pendidikan Nasional. Jakarta. www.ftp.lipi.go.id. 22 Oktober 2010. 284 hal.

Haetami, K., I. Susangka dan Y. Adriani. 2007. Kebutuhan dan Pola Makan Ikan Jambal Siam dari Berbagai Tingkat Pemberian 
Energi Protein Pakan Dan Pengaruhnya Terhadap Pertumbuhan dan Efisiensi. Skripsi. Fakultas Perikanan dan Ilmu Kelautan Universitas Padjajaran. www.pustaka.unpad.ac.id. 01 Maret 2011. 40 hal.

Kordi, M. G. H. K. 2010. Budidaya Ikan Patin di Kolam Terpal. Lily Publisher. Yogyakarta. hal. 1-14.

Kusriningrum, R. S. 2008. Perancangan Percobaan. Universitas Airlangga. Surabaya. hal. 4363.

Lovell, T. 1988. Nutrition and Feeding of Fish. Auburn University. New York. ISBN 0442-25927-1. hal. 19.

Mudjiman, A. 1994. Makanan Ikan. Penebar Swadaya. Jakarta. hal. 107.

Mudjiman, A. 2001. Makanan Ikan. Penebar Swadaya. Jakarta. hal. 100-178.

Murtidjo, B. A. 1987. Pedoman Meramu Pakan Unggas. Kanisius. hal. 1-73.
Narbuko, C. dan A. Achmadi. 2004. Metodologi Penelitian. PT. Bumi Aksara. Jakarta. hal 51-52.

Sahwan, M. F. 2002. Pakan Ikan dan Udang. Penebar Swadaya. Jakarta. 95 hal.

Sogbesan, A. O and Ugwumba A. A. A. Nutritional Values of Some Non-Conventional Animal Protein Feedstuffs Used as Fishmeal Supplement in Aquaculture Practices in Nigeria. University of Ibadan. Ibadan. Nigeria. 2 hal.

Umphan, K. M. 2009. Growth Performance, Sex Hormone Levels and Maturation Ability of Pla Pho (Pangasius bocourti) Fed with Spirulina Supplementary Pellet and Hormone Application. International Journal of Agriculture and Biology, 11: 458-462. www.fspublisher.org. 21 Oktober 2010. 4 hal.

Wilson, R. P. 1994. Utilization of Different Carbohydrate by Fish. Aquaculture 124, 6780 